\title{
PENGARUH GENDER DAN ROMBONGAN BELAJAR TERHADAP KEMAMPUAN PENALARAN MATEMATIS SISWA BOARDING SCHOOL
}

\author{
Depi Ardian Nugraha \\ Pendidikan Matematika, FKIP, Universitas Siliwangi Tasikmalaya \\ e-mail: depi@unsil.ac.id
}

\begin{abstract}
This study aims to determine the effect of gender (male and female) on the mathematical reasoning abilities of Boarding School students Darussalam Rajapolah Tasikmalaya for the 2019/2020 academic year; to determine the effect of study groups (Regular and Intensive) on the mathematical reasoning abilities of Boarding School students Darussalam Rajapolah Tasikmalaya Academic Year 2019/2020; as well as to determine the effect of gender and study groups (Regular and Intensive) on the mathematical reasoning abilities of Boarding School Darussalam Rajapolab Tasikmalaya students for the 2019/2020 Academic Year. This research belongs to the type of quantitative research with the research method used, namely the quasi-experimental method. The population in this study were all high school students at the Darussalam Rajapolah Tasikmalaya Boarding School for the 2019/2020 Academic Year, totaling 13 classes. The selected sample consisted of 4 classes, namely class X (equivalent to classes in general) male and female. Data collection techniques by giving tests of mathematical reasoning abilities, questions in the form of descriptions. The data analysis technique used is the TwoWay Anova Test with a significant level of 5\%. The results showed that: there was no significant effect of gender on the mathematical reasoning abilities of the boarding school students of Darussalam Rajapolah Tasikmalaya for the 2019/2020 academic year; there is a significant influence of the study group on the mathematical reasoning abilities of the boarding school students of Darussalam Rajapolah Tasikmalaya for the 2019/2020 academic year; there is no significant effect of gender interaction and study groups on the mathematical reasoning abilities of the Darussalam Rajapolah Tasikmalaya boarding school students for the 2019/2020 academic year.
\end{abstract}

Keywords: Gender, Study Groups, Regular, Intensive, and Boarding School.

\section{ABSTRAK}

Penelitian ini bertujuan untuk mengetahui pengaruh gender (laki-laki dan perempuan) terhadap kemampuan penalaran matematis siswa Boarding School Darussalam Rajapolah Tasikmalaya Tahun Ajaran 2019/2020; untuk mengetahui pengaruh rombongan belajar (Reguler dan Intensif) terhadap kemampuan penalaran matematis siswa Boarding School Darussalam Rajapolah Tasikmalaya Tahun Ajaran 2019/2020; serta untuk mengetahui pengaruh gender dan rombongan belajar (Reguler dan Intensif) terhadap kemampuan penalaran matematis siswa Boarding School Darussalam Rajapolah Tasikmalaya Tahun Ajaran 2019/2020. Penelitian ini termasuk kedalam jenis penelitian kuantitatif dengan metode penelitian yang digunakan yaitu metode kuasi eksperimen. Populasi pada penelitian ini adalah seluruh siswa SMA di Boarding School Darussalam Rajapolah Tasikmalaya Tahun Ajaran 2019/2020 sebanyak 13 kelas. Sampel yang terpilih sebanyak 4 kelas, yaitu kelas X (setara dengan kelas pada umumnya) laki-laki dan perempuan. Teknik pengumpulan data dengan cara memberikan tes kemampuan penalaran matematis, soal bentuk uraian. Teknik analisis data yang digunakan yaitu Uji Anova Dua Jalur dengan taraf signifikan 5\%. Hasil penelitian menunjukkan bahwa : tidak terdapat pengaruh yang signifikan gender terhadap kemampuan penalaran matematis siswa boarding school Darussalam Rajapolah Tasikmalaya Tahun Ajaran 2019/2020; terdapat pengaruh yang signifikan rombongan belajar yang signifikan terhadap kemampuan penalaran matematis siswa boarding school Darussalam Rajapolah Tasikmalaya Tahun Ajaran 2019/2020; tidak terdapat pengaruh yang signifikan interaksi gender dan rombongan belajar terhadap kemampuan penalaran matematis siswa boarding school Darussalam Rajapolah Tasikmalaya Tahun Ajaran 2019/2020.

Kata Kunci: Gender, Rombongan Belajar, Reguler, Intensif, dan Boarding School.

Submitted Aug 08, 2020 | Revised Oct 22, 2020 | Accepted Nov 22, 2020

\section{Pendahuluan}

Banyak upaya yang dilakukan oleh pemerintah atau masyarakat untuk membantu menyelenggaraan pendidikan di Indonesia, diantaranya adalah dengan mendirikan sekolah formal atau non formal, pesanten atau boarding school. Pembangunan pesantren dan penyelenggaraan boarding school di 
Indonesia kini menjadi suatu trend baru di Indonesia hal ini sesuai dengan data yang dikeluarkan oleh Kementrian Agama pada portal Pangakalan Data Pondok Pesantren (PDPP) bahwa saat ini jumlah pondok pesantren atau boarding school yang terdata oleh Kementerian Agama sebanyak 27.722 dengan jumlah santri sebanyak 4.175.467. Hal ini jauh berbeda dengan kondisi data yang diperoleh pada tahun 2005 yaitu terdapat 14.798 pesantern dengan total santri sebanyak 2.737.805. Bahkan Menteri Agama Fachrul Razi mendetailkan, jumlah pesantren hingga tahun 2020 ini tercatat sebanyak 28.194 pesantren dengan 5 juta santri mukim. "Kalau ditotalkan dengan santri yang bolak balik rumah ke pondok pesantren dan sebaliknya serta taman-taman pendidikan Al-Qur'an dan madrasah, maka jumlah santri kita sebanyak 18 juta orang dengan kurang lebih 1,5 juta tenaga pengajar,". sebut Menteri Agama saat menutup acara Forum Musyawarah Pondok Pesantren (FMPP) se-Jawa dan Madura di Pondok Pesantren Lirboyo, Kediri, Jawa Timur pada Jumat (14/02/2020).

Hal ini memberikan gambaran bahwa saat ini banyak sekali orang tua yang memasukan anaknya ke pondok pesantren atau boarding school, dengan harapaan anaknya bisa memiliki akhlak yang lebih baik. Pondok pesantren dan boarding school memiliki kesamaan dan perbedaan, kesamaanya adalah samasama merupakan sebuah lembaga pendidikan yang memberikan fasilitas asrama untuk para siswa / santrinya, kemudian santri yang belajar di pesantren dan boarding school sama-sama berasal dari berbagai daerah. Ada yang berasal dari lingkungan sekitar, ada juga dari berbagai penjuru daerah di dalam negeri maupun luar negeri.

Sedangkan perbedaan antara pesantren dengan boarding school adalah pesantren merupakan tempat untuk membentuk manusia yang berakhlak, dimana santri-santri tersebut bisa belajar tanpa adanya batas waktu serta kurikulum yang digunakan biasanya ditentukan oleh pihak pendiri atau pemimpin pesantren. Selain itu, tidak ada pembatasan umur bagi santri yang belajar di pondok pesantren, dan tempat pesantren biasanya mengambil tempat yang jauh dari hiruk pikuk keramaian. sedangkan untuk boarding school merupakan suatu tempat untuk para pelajar melakukan semua aktifitas seperti belajar, tinggal (tempat tinggal), serta aktifitas lain yang mendukung terlaksananya pendidikan, dengan batas waktu yang telah ditentukan, sehingga ada persyaratan umur bagi para siswa santrinya. Tempat belajar bagi para siswa biasanya mengambil tempat yang strategis atau jadi satu antara asrama dan sekolah, bahkan ada juga yang sampai memodifikasi sekolah formal. Oleh sebab itu, boarding school disebut juga dengan sekolah berasrama atau pesantren modern.

Pondok pesantren modern adalah salah satu lembaga yang menerapkan sistem boarding school yaitu suatu sistem intensif untuk pendidikan, di mana siswa tinggal di lingkungan sekolah dalam bentuk asrama dan orang tua bisa mengunjungi mereka dalam waktu seminggu atau sebulan sekali (Behaghel, Chaisemartin \& Gurdand, 2017)

Minat masyarakat terhadap hadirnya sekolah boarding school dengan sistem pendidikan Islamic Boarding school semakin meningkat, hal ini dikarenakan banyaknya lingkungan negatif yang mempengaruhi siswa akibat dari era globalisasi modern. Modernitas membawa implikasi negatif terhadap ketidakseimbangan antara kebutuhan rohani dan jasmani. Sekarang ini banyak anak didik bangsa yang terpengaruh dampak negatif dari globalisasi misal narkoba, seks bebas, tawuran remaja dan lain-lain. Para orang tua mengharapkan agar anaknya dapat terhindar dari dampak negatif globalisasi melalui sistem pendidikan Islamic boarding school.

Di Kabupaten Tasikmalaya khususnya, saat ini sudah memiliki beberapa sekolah berasrama yang berada dekat dengan pusat pemerintahan dan sebagian di antaranya merupakan pesantren modern dan beberapa lagi adalah boarding school. Boarding school Darussalam Rajapolah Tasikmalaya dikenal sebagai pesantren modern dengan sistem Islamic boarding school. Boarding school ini mengadopsi 3 kurikulum sekaligus, kurikulum untuk pelajaran kepondokannya diadopsi dari kurikulum KMI Darussalam Gontor Ponorogo. Sementara untuk pelajaran umum mengadopsi Kurikulum Kemendikbud dan untuk Pelajaran Kitab Kuning menganut Kurikulum Salafiyah dari Pondok Salafiyah Tebuireng Jombang Jawa Timur. 
Dikombinasikannya sistem kurikulum kepondokmodernan Gontor, Salafiyah Kitab Kuning serta Kemendikbud sebagai kebutuhan akan tuntutan globalisasi dengan berkembangnya ilmu sains dan teknologi. Berdasarkan adanya tiga kurikulum dan orientasi keahlian yang ingin dicapai oleh siswa seperti bahasa dan ilmu pengetahuan agama di pondok pesantren modern menjadikan siswa mempelajari banyak mata pelajaran, sehingga timbul pertanyaan peneliti adakah hal tersebut (kombinasi sistem kurikulum) mempengaruhi kemampuan siswa pada mata pelajaran eksakta seperti Mata Pelajaran Matematika.

Salah satu harapan yang ingin dicapai dalam pembelajaran matematika di Sekolah Menengah Atas (SMA) berdasarkan kurikulum yang berlaku pada saat ini adalah dimilikinya kemampuan matematis. Kemampuan matematis khususnya kemampuan penalaran matematis sangat diperlukan siswa terkait untuk memecahkan masalah dalam kehidupan sehari-hari. Oleh sebab itu, kemampuan matematis terutama yang menyangkut doing math (aktivitas matematika) perlu mendapatkan perhatian khusus dalam proses pembelajaran matematika. Kemampuan penalaran matematis yaitu kemampuan menghubungkan permasalahan-permasalahan ke dalam suatu ide atau gagasan sehingga dapat menyelesaikan permasalahan matematis. Terkait dengan kemampuan matematis, Sofyan (2008, p.42) melakukan penelitian tentang proses berpikir matematis siswa dalam menyelesaikan soal-soal geometri, dari penelitiannya ditemukan bahwa, ada siswa yang berpikir sistematis, dan menggunakan konsep sebelumnya dalam mengerjakan soal dan ini dinamakan proses berpikir konseptual. Kemudian ada siswa yang berpikir lamban, tidak sistematis, dan cenderung cepat menyerah, serta cepat lupa dan ini dinamakan proses berpikir sekuensial. Dengan berkembangnya kemampuan penalaran matematis siswa, berkembang pula kemampuannya dalam memecahkan masalah matematika. Sebelum siswa dihadapkan pada masalah kehidupan nyata yang sangat kompleks, kemampuan dalam memecahkan masalah perlu terus diasah dan ditingkatkan. Hal ini juga sejalan dengan pendapat Polya (1977, p.35) yaitu apabila siswa memiliki kemampuan dan keterampilan pemecahan masalah, maka mereka akan terbiasa menghadapi masalah lainnya.

Pembelajaran matematika juga merupakan salah satu bagian dari pendidikan yang melatih siswa dalam mengembangkan kemampuan penalarannya. Hal ini sejalan dengan pendapat Sumarmo (dalam Hendriana, Rohaeti \& Sumarmo, 2017) "Pembelajaran matematika diarahkan untuk memberi peluang berkembangnya kemampuan bernalar, kesadaran terhadap kebermanfaatan matematika, menumbuhkan rasa percaya diri, sikap objektif dan terbuka untuk menghadapi masa depan yang selalu berubah" (p. 25).

Pada saat ini siswa menganggap pelajaran matematika itu sulit, sehingga pada proses pembelajarannya tidak sedikit siswa yang tidak mengerti dan memahami konsep materi yang disampaikan. Selain itu Wahyudin (dalam Sumartini, 2015) mengatakan "Salah satu kecenderungan yang menyebabkan siswa gagal menguasai dengan baik pokok-pokok bahasan dalam matematika yaitu siswa kurang memahami dan menggunakan nalar yang baik dalam menyelesaikan soal yang diberikan" (p. 1). Padahal kemampuan penalaran menjadi salah satu tujuan dalam pembelajaran matematika di sekolah yaitu dapat melatih cara berpikir dan menalar dalam menarik sebuah kesimpulan serta mengembangkan kemampuan memecahkan masalah.

Boarding School Darussalam Rajapolah Tasikmalaya menerapkan proses pembelajaran dengan memisahkan rombongan belajar berdasarkan gender (identitas gender) dan juga memisahkan rombongan belajar antar kelas intensif dan reguler. Jenjang pendidikan pada boarding school ini terdiri dari SMP Terpadu dan SMA Terpadu yang sifatnya Terbuka. Sistem pembelajaran di pesantren ini diklasifikasikan dalam sistem kelas reguler dan kelas intensif. Kelas Reguler diperuntukkan bagi para siswa yang masuk pondok mulai dari kelas 1 (Kelas VII) sampai dengan kelas 6 (Kelas XII), sementara kelas Intensif bagi para siswa yang bukan berasal dari SMPT Darussalam Rajapolah Tasikmalaya. Jika siswa pada Kelas Reguler mengalami pembelajaran minimal 6 tahun, maka untuk siswa kelas intensif minimal 4 tahun, kecuali dia yang lulus dalam mengikuti tes akselerasi. Kemudian berdasarkan hasil 
observasi tersebut maka muncul pertanyaan sebagai peneliti adakah perbedaan kemampuan penalaran matematis siswa diakibatkan perbedaan gander dan rombongan belajar (reguler dan intensif) dalam proses belajar di pondok pesantren modern tersebut terutama dalam pelajaran matematika?. Peneliti memilih boarding school Darussalam Rajapolah Tasikmalaya sebagai tempat penelitian karena bisa dipastikan di Kab./kota Tasikmalaya ini hanya boarding school Darussalam Rajapolah yang menerapkan sistem reguler dan intensif .

Berdasarkan hasil observasi di boarding school Darussalam Rajapolah Tasikmalaya yaitu di tingkat SMA Terpadu, hasil belajar matematika siswa SMA Terpadu Darussalam Rajapolah Tasikmalaya sangat bervariasi, dan dipengaruhi dari beberapa faktor. Berdasarkan hasil wawancara tidak terstruktur dengan guru mata pelajaran matematika terjadinya perbedaan hasil belajar matematika ini dipengaruhi oleh banyak faktor, baik dari dalam maupun dari luar diri siswa (internal dan eksternal). Faktor internal yang mempengaruhi hasil belajar matematika siswa SMA ini adalah tingkat kedisiplinan, minat belajar, gaya belajar, kemampuan penalaran siswa dalam menyelesaikan/memecahkan permasalahan matematika, jenis kelamin siswa, dan masih banyak faktor lainnya.

Klasifikasi tersebut membuat berbagai pandangan guru-guru matematika yang mengajar di pesantren ini. Ada yang mengatakan bahwa siswa intensif lebih mudah menerima materi dan memahami materi yang disampaikan. Tetapi ada juga guru matematika lain yang sama mengajar di sana mengatakan bahwa siswa reguler lebih mudah menerima dan memahami materi yang disampaikan. Dilihat dari hasil belajar matematis kelas reguler dan intensif dari Ujian Akhir Semester 1 Tahun Ajaran 2019/2020 diperoleh siswa perempuan reguler lebih unggul dari siswa laki- laki reguler dan siswa intensif laki-laki lebih unggul dari siswa intensif perempuan dalam nilai ulangan ataupun ujian akhir. Oleh karena itu penulis ingin mengetahui lebih dalam tentang hal tersebut. Pada penelitian ini penulis membatasi faktor yang mempengaruhi kemampuan penalaran matematis siswa yaitu berdasarkan gender dan rombongan belajar (reguler dan intensif).

Berdasarkan latar belakang yang telah diuraikan maka tujuan penelitian ini adalah untuk mengetahui: 1) apakah terdapat pengaruh gender laki-laki/perempuan terhadap kemampuan penalaran matematis siswa boarding school Darussalam Rajapolah, 2) adakah pengaruh rombongan belajar (reguler dan intensif) terhadap kemampuan penalaran matematis siswa boarding school Darussalam Rajapolah, 3) adakah pengaruh interaksi jenis kelamin dan kelompok belajar (reguler dan intensif) terhadap kemampuan penalaran matematis siswa boarding school Darussalam Rajapolah.

Pengaruh gender dan rombongan belajar (reguler dan intensif) terhadap kemampuan penalaran matematis siswa boarding school diperoleh dari kuadrat hasil korelasi gender dan rombongan belajar terhadap kemampuan penalaran matematis siswa boarding school. Artinya dikatakan berpengaruh apabila perpaduan antara gender dan rombongan belajar dapat mempengaruhi baik buruknya kemampuan penalaran matematis siswa boarding school Darussalam Rajapolah.

Kemampuan penalaran matematis yaitu kemampuan menghubungkan permasalahanpermasalahan ke dalam suatu ide atau gagasan sehingga dapat menyelesaikan permasalahan matematis. Menurut Sardin (dalam Lestari \& Prahmana, 2017) "Penalaran merupakan proses berpikir dalam penarikan kesimpulan dengan cara menghubungkan fakta yang ada di kehidupan sehari-hari" (p.153). sedangkan menurut Lithner (dalam Rosita, 2014) "Penalaran adalah pemikiran yang di adopsi untuk menghasilkan pernyataan dan mencapai kesimpulan pada pemecahan masalah yang tidak selalu didasarkan pada logika formal sehingga tidak terbatas pada bukti” (p.33).

Sedangkan merurut Sumarmo (2013) "Kemampuan penalaran matematis merupakan kemampuan dan kegiatan dalam otak yang harus dikembangkan berkelanjutan melalui suatu konteks" (p.198). Selain itu, Turmudi (dalam Sumartini, 2015) menyatakan "Kemampuan penalaran matematis merupakan suatu kebiasaan otak seperti halnya kebiasaan lain yang harus dikembangkan secara konsisten menggunakan berbagai macam konteks, mengenal penalaran dan pembuktian merupakan aspek-aspek fundamental dalam matematika" (p.2). 
Sumarmo (2013) memberikan sembilan indikator kemampuan penalaran matematis yaitu: (1) Menarik kesimpulan logis (2) Memberikan penjelasan degan menggunakan model, fakta, sifat, dan hubungan (3) Memperkirakan jawaban dan proses solusi (4) Menggunakan pola dan hubungan untuk menganalisis situasi matematis menarik analogi, dan generalisasi (5) Menyusun dan menguji konjektur (6) Memberikan lawan contoh (counter examples) (7) Mengikuti aturan inferensi; memeriksa validitas argumen (8) Menyusun argumen yang valid (9) Menyusun pembuktian langsung, pembuktian tak langsung, dan induksi matematis (p.6).

Indikator kemampuan penalaran matematis yang akan digunakan pada penelitian ini, yaitu : melaksanakan perhitungan berdasarkan aturan atau rumus tertentu; menari analogi dan generalisasi; memberi penjelasan terhadap fakta, hubungan yang ada. Kemampuan penalaran matematik diperoleh dari hasil tes kemampuan penalaran matematis siswa

Istilah gender sudah sangat sering digunakan dalam berbagai bidang ilmu, seperti bidang pendidikan, bidang kesehatan, maupun bidang ekonomi, serta bidang-bidang ilmu lainnya. Menurut Santrock (2007) bahwa gender merupakan suatu dimensi psikologis dan sosiokultural yang dimiliki karena seseorang adalah laki-laki atau perempuan (p.84). Oakley (dalam Relawati, 2011) mendefinisikan gender adalah perbedaan kebiasaan/tingkah laku antara perempuan dan laki-laki yang dikonstruksikan secara sosial, yang dibuat oleh laki-laki dan perempuan itu sendiri, hal tersebut merupakan bagian dari kebudayaan.

Gender merupakan perbedaan kebiasaan/tingkah laku antara laki-laki dan perempuan yang dikontruksikan secara social dan ditetapkan oleh masyarakat berdasarkan peran dan kedudukan yang dianggap pantas sesuai norma-norma, adat istiadat, kepercayaan, atau kebiasaan masyarakat. Gender juga memiliki beberapa aspek penting yang ada di dalamnya. Ada dua aspek penting dari gender: identitas gender dan peran gender. Identitas gender merupakan identitas sebagai laki-laki atau perempuan, dan peran gender merupakan sebuah set ekspektasi yang menggambarkan bagaimana laki-laki atau perempuan seharusnya berpikir, bertindak, atau merasa (Santrock, 2007, p.48). Pada penelitian ini, aspek gender yang diteliti adalah identitas gender. Identitas gender merupakan identitas sebagai laki-laki atau perempuan.

Selain perbedaan gender atau pengklasifikasian kelas berdasarkan gender, program pendaftaran santri baru di boarding school Darussalam Rajolah Kabpaten Tasikmalaya, ketika penerimaan santri baru terdapat Program Kelas Reguler dan Kelas Intensif. Para santri baru di pesantren terbagi menjadi kelas satu reguler dan kelas satu intensif. Kelas satu reguler (untuk para santri baru lulusan Sekolah Dasar atau sederajat), dengan program pendidikan akademis dalam jangka waktu minimal 6 tahun. Sedangkan kelas satu intensif (untuk para santri baru yang berasal dari lulusan sekolah menengah) merupakan program pendidikan akademis dengan jangka waktu minimal 4 tahun. diungkapkan oleh KH. MasyhudiSubari, MA., Direktur KMI Gontor (dalam Majalah Gontor "Acara Pengumuman Kelas Santri Baru”).

Pemisahan kelas di Pondok Pesantren Darussalam Rajapolah Tasikmalaya sendiri dimaksudkan untuk penyeimbangan mata pelajaran yang harus didapatkan oleh siswa. Siswa reguler mempelajari mata pelajaran pondok dari Kelas 1, sementara yang mengikuti program kelas intensif artinya lulusan SMP luar Darussalam Rajapolah itu mempelajari mata pelajaran pondok 2 tingkat (kelas 1 dan kelas 2) sekaligus dalam satu tingkat. Pada kelas 1 intensif ini, siswa belum mempelajari mata pelajaran umum karena agar siswa bisa beradaptasi terlebih dahulu dan menyesuaikan program SMA Kemendikbud yang 3 tahun. Sementara di kelas 3 intensif, siswa mempelajari mata pelajaran pondok 2 tingkat (kelas 3 dan kelas 4) sekaligus disertai mata pelajaran umum kelas X. Setelah itu barulah disatukan anatar yang intensif dan reguler di kelas 5 , karena sudah setara mata pelajaran pondok yang mereka pelajari.

Rombongan belajar (reguler dan intensif) ini tidak diterpakan oleh semua pondok alumni Gontor atau Pondok yang mengadopsi kurikulum KMI Gontor. "Bisa di pastikan di Kab./kota 
Tasikmalaya ini hanya boarding school Darussalam Rajapolah yang menerapkan sistem reguler dan intensif " tutur KH. Ahmad Deni Rustandi, M.Ag. (Pimpinan Pondok dan ketua IKPM Gontor Tasikmalaya) dalam Rapat Kamisan 13 Februari 2020.

Sistem pendidikan dengan pola boarding school, mengharuskan siswanya mengikuti kegiatan pendidikan reguler dari pagi sampai siang hari kemudian dilanjutkan dengan kegiatan pendidikan dengan nilai-nilai khusus pada sore dan malam hari misalkan; kegiatan pengkajian Al-Qur'an di pesantren, kegiatan ekstrakurikuler, kegiatan pembinaan disiplin dan lain sebagainya. Di Indonesia terdapat ratusan bahkan mungkin ribuan institusi pendidikan yang menerapkan boarding school, dan tersebar di berbagai provinsi seperti; pondok pesantren, sekolah-sekolah gereja, institusi pendidikan kedinasan (IPDN, Akmil, Akpol, Sekolah Tinggi Pelayaran, STKS, STT'-Telkom, dan lain-lain).

Menurut Khalidah (dalam Anisa Rizkiani, 2012, p.13) Boarding School merupakan kata dalam bahasa inggris yang terdiri dari dua kata yaitu boarding dan school, boarding berarti menumpang dan school berarti sekolah, kemudian diserap ke dalam bahasa Indonesia menjadi sekolah berasrama. Asrama adalah rumah pemondokan untuk para siswa, pegawai dan sebaginya, sedangkan berasrama yaitu tinggal bersama-sama di dalam suatu bangunan atau komplek.

Menurut Maksudin (2006:15) Boarding school adalah lembaga pendidikan di mana para siswa tidak hanya belajar, tetapi mereka bertempat tinggal dan hidup menyatu di lembaga tersebut. Boarding school mengombinasi tempat tinggal para siswa di institusi sekolah yang jauh dari rumah dan keluarga mereka dengan diajarkan agama serta pembelajaran beberapa mata pelajaran di tempat yang sama.

Berdasarkan penjelasan yang telah diuraikan mengenai boarding school maka dapat disimpulkan bahwa boarding school adalah sistem sekolah berasrama di mana selain belajar sebagian besar siswa dan guru juga bermukim di suatu tempat atau kompleks yang sama. Boarding school mengharuskan siswanya mengikuti kegiatan reguler dari pagi sampai siang hari kemudian dilanjutkan kegiatan pendidikan dengan nilai-nilai khusus pada sore dan malam hari.

\section{Metode Penelitian}

Penelitian ini termasuk pada jenis penelitian kuantitaif dan metode penelitian yang digunakan pada penelitian ini adalah metode kuasi eksperimen. Menurut Arikunto (2010) "Pre Experimental Design seringkali dipandang sebagai eksperimen yang tidak sebenarnya. Oleh karena itu, sering disebut juga dengan istilah quasi experiment (p. 123). Pada penelitian kuasi eksperimen, tidak semua aspek dalam penelitian ini diberikan perlakuan oleh peneliti, tetapi ada beberapa hal yang tetap seperti keadaan awal yaitu seperti pengelompokan subjek yang akan dijadikan sampel penelitian. Peneliti mengambil sampel berdasarkan kelompok alami yang sudah ada yaitu berupa kelas-kelas yang telah terbentuk.

Desain yang digunakan dalam penelitian ini adalah desain causal comparative. Causal comparative merupakan jenis penelitian yang digunakan untuk membandingkan antara dua kelompok atau lebih dari suatu variabel tertentu (Arifin, 2012, p.46). Penelitian komparatif ini memiliki tujuan untuk melihat perbedaan dua atau lebih situasi, peristiwa, kegiatan, atau program yang sejenis atau hampir sama yang melibatkan semua unsur atau komponennya. Analisis penelitian dilakukan terhadap perbedaan dalam perencanaan, pelaksanaan, faktor-faktor pendukung dan hasil. Hasil analisis perbandingan dapat menemukan unsur-unsur atau faktor-faktor penting yang melatarbelakangi persamaan dan perbedaan.

Populasi pada penelitana ini adalah seluruh siswa Boarding School SMA Terpadu Darussalam Rajapolah Tasikmalaya, berikut disajikan pada Tabel 1.

Tabel 1. Populasi Penelitian

\begin{tabular}{ccc}
\hline Kelas & Jumlah Siswa & Keterangan \\
\hline 1 Intensif B & 25 & Laki-laki \\
\hline 1 Intensif C & 33 & Perempuan \\
\hline
\end{tabular}


Nugraba, Pengaruh gender dan rombongan belajar...

\begin{tabular}{ccc}
\hline 3 Intensif B & 21 & Laki-laki \\
\hline 3 Intensif C & 30 & Perempuan \\
\hline 4B & 30 & Laki-laki \\
\hline 4C & 25 & Perempuan \\
\hline 5B & 33 & Laki-laki \\
\hline 5C & 25 & Perempuan \\
\hline 5D & 25 & Perempuan \\
\hline 6B IPA & 14 & Laki-laki \\
\hline 6C IPA & 29 & Perempuan \\
\hline 6B IPS & 21 & Laki-laki \\
\hline 6C IPS & 18 & Perempuan \\
\hline Total & &
\end{tabular}

Sumber: Staf KMI Darussalam (Tata Usaha SMAT Darussalam)

Teknik penarikan sampel pada penelitian ini menggunakan teknik clustered randome sampling, sehingga terpilih 4 kelas yaitu kelas 3 Intensif B (laki-laki), 3 Intensif C (perempuan), 4 Reguler B (laki-laki) dan 4 Reguler C (perempuan). Keempat kelas tersebut setara dengan kelas X pada umumnya. Peneliti mengambil sampel tersebut karena pada tingkatan ini siswa Reguler dan Intensif masih di pisah rombongan belajarnya, sementara untuk kelas 1 Intensif belum mempelajari mata pelajaran umum.

Teknik pengumpulan data pada penelitian ini yaitu dengan cara memberikan soal tes kemampuan penalaran matematis kepada seluruh sampel penelitian, sedangkan instrummen penelitian yang digunakan berupa soal tes kemampuan penalaran matematis yang berbentuk uraian.

Teknik analisis data menggunakan uji statistika parametrik yaitu uji anova dua jalur (Two Way Anova). Proses analisis data dibantu dengan menggunakan software statistika IBM SPSS versi 25.0. Proses analisis data diawali dengan uji prasyarat normalitas dan homogenitas data kemudian dilanjutkan dengan melakukan uji hipotesis dengan menggunakan anova dua jalur.

Penelitian ini dilaksanakan di boarding school Darussalam Rajapolah Tasikmalaya bertempat di Kp. Narunggul Ds. Tanjungpura Kec. Rajapolah Kab. Tasikmalaya berdiri pada tahun 2007. Kurikulum yang dilaksanakan di SMA Terpadu Darussalam Rajapolah Tasikmalaya yaitu untuk pelajaran umum adalah Kurikulum 2013.

\section{Hasil dan Pembahasan}

Data Hasil penelitian yang telah dikumpulkan yaitu yang berupa hasil tes kemampuan penalaran matematis siswa kemudian dianalisis, berikut deskripsi hasil analisis tes kemampuan penalaran matematis yang sudah dihimpun, disajikan pada Tabel 4.

Tabel 4. Deskripsi Hasil Tes Kemampuan Penalaran Matematis

\begin{tabular}{|c|c|c|c|c|}
\hline \multirow{2}{*}{ Gender } & \multirow{2}{*}{ Statistik } & \multicolumn{2}{|c|}{ Kelompok Belajar } & \multirow{2}{*}{ Total } \\
\hline & & Reguler & Intensif & \\
\hline \multirow[t]{4}{*}{ Laki-Laki } & $\mathrm{N}$ & 30 & 21 & 51 \\
\hline & Rata-rata & 14,40 & 11.7000 & 12,70 \\
\hline & SB & 2,27 & 2.63 & 2,45 \\
\hline & $\mathrm{KV}(\%)$ & 15,75 & 23.88 & 19,82 \\
\hline \multirow[t]{4}{*}{ Perempuan } & $\mathrm{N}$ & 25 & 30 & 55 \\
\hline & Rata-rata & 15,12 & 11.40 & 13.26 \\
\hline & SB & 2.26 & 2.51 & 2.39 \\
\hline & $\mathrm{KV}(\%)$ & 14.95 & 22.05 & 18.50 \\
\hline \multirow[t]{4}{*}{ Total } & $\mathrm{N}$ & 55 & 51 & 106 \\
\hline & Rata-rata & 14,76 & 11,20 & 12,98 \\
\hline & SB & 2.26 & 2.57 & 2.42 \\
\hline & $\mathrm{KV}(\%)$ & 15.35 & 22.96 & 19.16 \\
\hline
\end{tabular}


Berdasarkan hasil analisis data pada Tabel 4 dapat dijelaskan bahwa: rata-rata hasil tes kemampuan penalaran matematis siswa Boarding School Darussalam Rajapolah pada siswa perempuan lebih besar daripada rata-rata siswa laki-laki, Simpangan baku (SB) dan koefisien variansi (KV) hasil tes kemampuan penalaran matematis siswa Boarding School pada perempuan lebih kecil daripada lakilaki. Hal ini menggambarkan bahwa hasil tes kemampuan penalaran matematis siswa Boarding School pada siswa perempuan lebih baik daripada hasil tes laki-laki. Artinya, perempuan memiliki kemampuan penalaran matematis yang lebih mumpuni dibandingkan laki-laki.

Hasil analisis data pada Tabel 4 juga menjelaskan bahwa secara keseluruhan rata-rata kemampuan penalaran matematis pada Kelas Reguler lebih besar daripada Kelas Intensif, sementara SB dan KV data hasil tes kemampuan penalaran matematis Kelas Reguler lebih kecil daripada Kelas Intensif. Hal ini menggambarkan bahwa kemampuan penalaran matematis siswa Kelas Reguler lebih baik dan lebih seragam daripada Kelas Intensif. Artinya, siswa Kelas Reguler mempunyai kemampuan penalaran matematis yang lebih mumpuni dibandingkan Kelas Intensif.

Untuk menjawab rumusan masalah dan menguji hipotesis penelitian maka setelah data terkumpul dilakukan uji prasyarat yaitu uji normalitas dan homogenitas data, yang hasilnya data berdistribusi normal dan homogen. Setelah itu untuk menguji hipotesis penelitan dilakutkan analisis data dengan menggunakan uji anova dua jalur (two way anova), Hasilnya analisis data seperti data pada Tabel 5 .

Tabel 5. Hasil Uji Anova Dua

\begin{tabular}{lrlccc}
\hline \multicolumn{1}{c}{ Source } & $\begin{array}{c}\text { Type III Sum } \\
\text { of Squares }\end{array}$ & df & Mean Square & F & Sig. \\
\hline Corrected Model & $331.724^{\mathrm{a}}$ & 3 & 110.575 & 19.018 & 0.000 \\
\hline Intercept & 17472.041 & 1 & 17472.041 & 3005.106 & 0.000 \\
\hline Gender & 8.130 & 1 & 8.130 & 1.398 & 0.240 \\
\cline { 1 - 4 } Rombel & 328.575 & 1 & 328.575 & 56.513 & 0.000 \\
\hline Gender * Rombel & 0.664 & 1 & 0.664 & 0.114 & 0.736 \\
\cline { 1 - 3 } Error & 593.040 & 102 & 5.814 & & \\
\cline { 1 - 4 } Total & 18969.000 & 106 & & & \\
\cline { 1 - 3 } Corrected Total & 924.764 & 105 & & &
\end{tabular}

Hasil analisis data untuk menguji hipotesis yang pertama yaitu terdapat pengaruh gender terhadap kemampuan penalaran matematis siswa Boarding School Darussalam Rajapolah, maka berdasarkan data pada Tabel 5, diperoleh nilai (Sig.) untuk gender sebesar 0,240. Hal ini menunjukkan bahwa nilai (Sig.) $>0,05$ (Alfa), berarti $H_{0}$ diterima, yang artinya tidak terdapat pengaruh gender terhadap kemampuan penalaran matematis siswa Boarding School. Hasil tersebut menunjukkan bahwa tidak adanya pengaruh yang signifikan pemisahan kelas berdasarkan gender terhadap kemampuan penalaran matematis siswa Boarding School Darussalam Rajapolah.

Hal ini sejalan dengan Reese, dkk. (dalam Joyce, 2011) yang juga menggali isu-isu gender dan kemudian mendapatkan suatu data, bahwa skor rata-rata NAEP dalam bidang matematika yang muncul dalam kurun waktu 1990 hingga 1960 menunjukkan bahwa perbedaan gender tidak lagi menjadi masalah serius, sebab rata-rata prestasi siswa wanita sering kali lebih tinggi dari prestasi yang dicapai siswa pria (beberapa dekade yang lalu, skor prestasi laki-laki jauh lebih tinggi dibanding perempuan). Hal serupa juga diungkapkan oleh Smetackova (2015) bahwa tidak ada peredaan yang signifikan antara laki-laki dan perempuan dalam hasil tes matematika, sehingga diasumsikan bahwa kemampuan laki-laki dan perempuan dalam bidang matematika itu sama (p. 218).

Hasil analisis data untuk menguji hipotesis yang kedua yaitu terdapat pengaruh rombongan belajar (Reguler dan Intensif) terhadap kemampuan penalaran matematis siswa Boarding School Darussalam Rajapolah, maka berdasarkan data pada Tabel 5, diperoleh nilai (Sig.) untuk rombongan 
belajar sebesar 0,000. Hal ini menunjukkan bahwa nilai (Sig.) $<0,05$ (Alfa), berarti $H_{0}$ ditolak, yang artinya terdapat pengaruh rombongan belajar (reguler dan intensif) terhadap kemampuan penalaran matematis siswa Boarding School. Hasil tersebut menunjukkan bahwa adanya pengaruh yang signifikan pemisahan kelas berdasarkan rombongan belajar (reguler dan intensif) terhadap kemampuan penalaran matematis siswa Boarding School Darussalam Rajapolah.

Hasil analisis data untuk menguji hipotesis yang ketiga yaitu terdapat pengaruh interaksi gender (laki-laki dan perempuan) dan rombongan belajar (Reguler dan Intensif) terhadap kemampuan penalaran matematis siswa Boarding School Darussalam Rajapolah, maka berdasarkan hasil analisis data pada Tabel 5, diperoleh nilai (Sig.) untuk interaksi pengaruh gender dan rombongan belajar sebesar 0,736. Hal ini menunjukkan bahwa nilai (Sig.) $>0,05$ (Alfa), berarti $H_{0}$ diterima, yang artinya tidak terdapat pengaruh iinterkasi gender dan rombongan belajar (reguler dan intensif) terhadap kemampuan penalaran matematis siswa Boarding School. Hasil tersebut menunjukkan bahwa tidak terdapat pengaruh interaksi yang signifikan pemisahan kelas berdasarkan gender dan rombongan belajar (reguler dan intensif) terhadap kemampuan penalaran matematis siswa Boarding School Darussalam Rajapolah.

Berdasarkan hasil perhitungan, pencapaian kemampuan penalaran matematis siswa Boarding School berdasarkan gender dapat terlihat dari pencapaian perindikator kemampuan penalaran matematis. Indikator pertama yaitu kemampuan dalam melaksanakan perhitungan berdasarkan aturan atau rumus tertentu diperoleh rata-rata laki-laki 3,78 dan rata-rata perempuan 3,83. Berdasarkan hasil penelitian ditemukan bahwa kebanyakan siswa perempuan mampu melaksanakan perhitungan dari soal dengan rumus yang tepat. Namun untuk siswa laki-laki mampu melaksanakan perhitungan dari soal tetapi belum menggunakan rumus yang tepat. Hasil tes pada indikator kedua yaitu menarik kesimpulan secara logis diperoleh rata-rata laki-laki 2,73 dan rata-rata perempuan 2,76 yang merupakan rata-rata terkecil. Berdasarkan hasil penelitian ditemukan bahwa sebagian dari siswa lakilaki dan perempuan telah mampu menghasilkan jawaban dengan menarik kesimpulan secara logis dari permasalahan matematika. Hasil tes pada indikator ketiga yaitu kemampuan memperkirakan jawaban dan solusi dengan rata-rata laki-laki 3,00 dan perempuan 3,52. Berdasarkan hasil penelitian di lapangan diperoleh hasil kebanyakan dari siswa perempuan dapat memperkirakan jawaban, dengan memberikan solusi yang tepat. Sedangkan hasil tes pada indikator keempat yaitu kemampuan untuk pembuktian langsung, dengan rata-rata pada laki-laki 3,20 dan perempuan 3,17 Berdasarkan hasil penelitian kebanyakan dari siswa laki-laki dan perempuan telah mampu membuktikan secara langsung dari rumus yang telah ditentukan.

\section{Kesimpulan}

Berdasarkan hasil pengolahan data dan analisis data terhadap hipotesis penelitian, maka diperoleh kesimpulan sebagai berikut: 1) tidak terdapat pengaruh yang signifikan gender (laki-laki dan perempuan) terhadap kemampuan penalaran matematis siswa boarding school Darussalam Rajapolah Tasikmalaya Tahun Ajaran 2019/2020; 2) terdapat pengaruh yang signifikan rombongan belajar (reguler dan intensif) terhadap kemampuan penalaran matematis siswa boarding school Darussalam Rajapolah Tasikmalaya Tahun Ajaran 2019/2020; dan 3) tidak terdapat pengaruh yang signifikan interaksi gender dan rombongan belajar (Reguler dan Intensif) terhadap kemampuan penalaran matematis siswa boarding school Darussalam Rajapolah Tasikmalaya Tahun Ajaran 2019/2020.

Saran dari hasil penelitian yang sudah dilakukan yaitu: 1) bagi pihak sekolah diharapkan dapat mencari solusi agar kemampuan penalaran matematis siswa Boarding School antara siswa reguler dan intensif seimbang. Bisa dengan dilakukan belajar malam khusus untuk anak intensif; 2) bagi guru sebaiknya lebih memahami keadaan siswa dan dapat memberikan perlakuan yang berbeda antara siswa kelas reguler dan intensif; 3) bagi peneliti selanjutnya yang akan meneliti tentang pemisahan rombongan belajar (Reguler dan Intensif) di Boarding School disarankan untuk mengembangkan 
penelitiannya lebih luas lagi, hasil penelitian ini bisa dijadikan acuan untuk melanjutkan penelitian pada materi ataupun kelas selanjutnya.

\section{Daftar Pustaka}

Anisa, Rizkiani. 2012. Pengaruh sistem boarding schoolterhadap pembentukan karakter peserta didik: Penelitian di Ma'had Darul Arqam Muhammadiyah Daerah Garut. Jurnal Pendidikan $\begin{array}{lllll}\text { Universitas } & \text { Garut,Vol. } & 06 ; & \text { No. } & 01 .\end{array}$ https://journal.uniga.ac.id/index.php/JP/article/view/45

Arifin, Z. (2021). Pendidikan Penelitian:Metode dan Paradigma Baru. Remaja Rosdakarya.

Arikunto. (2010). Prosedur Penelitian: Suatu Pendekatan Praktek. Jakarta: Rineka Cipta

Arikunto, S. (2015). Manajemen Penelitian. Jakarta, Indonesia: Asdi Mahasatya.

Behaghel, L., Chaisemartin, C. de, \& Gurgand, M. (2017). Ready for boarding? The effects of a boarding school for disadvantaged students. American Economic Joumal: Applied Economics, 9(1), 140-164. doi: 10.1257/app.20150090

Hendriana, H., Rohaeti, E.E., \& Soemarmo, U.. (2017). Hard Skills And Soft Skills Matematik Siswa. Bandung, Indonesia: Refika Aditama.

Joyce, Marsha Weil, Emily Calhoun. (2011). Models of Teaching, edisi 8. Yogyakarta: Pustaka Belajar

Lestari, Resti mardiana, Rulli Charista Indra Prahmana. 2017. Model Guided Inquiry, Student Team Achievment Division dan Kemampuan Penalaran Matematis Siswa. Jurnal Tadris Matematika. 10 (2), 153-165. [online] https://jumalbeta.ac.id/index.php/betaJTM/article/view/119

Maksudin. (2006). Pendidikan Nilai Sistem Boarding School di SMP IT Abu Bakar. Disertasi.

Polya, G. (1977). On Solving Matematical Problem In High SchooL Problem Solving In Matematic. NCTM.

Relawati, R. (2011). Konsep dan Aplikasi Penelitian Gender. Bandung, Indonesia: Muara Indah

Santrock, J. W. (2007). Child Development, eleventh edition (Mila Rachmawati \& Anna Kuswanti, Trans). Jakarta, Indonesia: Erlangga.

Smetackova, I. (2015). Gender Stereotypes, Performance and Identification with Math. Procedia-Social and Behavioral Sciences, 190, 211-219. doi: 10.1016/j.sbspro.2015.04.937

Sofyan, Deddy. (2008). Pembelajaran Berbasis Masalab untuk. Meningkatkan Kemampuan Pemecaban Masalab dan Kemampuan Komunikasi Matematik. Siswa SMP (Eksperimen terhadap Siswa Kelas VII di Satu SMPN di Kabupaten Garut). Tesis SPs UPI Bandung.

Sumarmo, U. (2013). Mengembangkan Kemampuan Penalaran dan Koneksi Matematik Siswa SMA Melalui Pembelajaran Berbasis Masalah.Dalam Suryadi, D., Turmudi dan Nurlaelah, E. (Penyelia), Kumpulan Makalah Berpikirdan Disposisi Matematik serta Pembelajarannya (hlm. 147 -158).Bandung: Jurusan Pendidikan Matematika Fakultas Pendidikan MIPA UPI.

Sumartini, T.S (2015). Peningkatan Kemampuan Penalaran Matematis Siswa Melalui Pembelajaran Berbasis Masalah. Jumal Mosharafa Vol. 4 No. 1 Tabun 2015, [online] https://journal.institutpendidikan.ac.id/index.php/mosharafa/article/view/mv4n1_1 